\title{
Mekanisasi Pertanian dan Nasib Buruh Tani Perempuan
}

Created: 04 July 2018

Pada masyarakat pedesaan yang notabene adalah masyarakat agraris, sudah menjadi hal yang ikhwal ketika terlihat para perempuan paruh baya pulang dari bekerja di sawah dengan wajah penuh lelah. Mereka bekerja untuk para tuan (pemilik) lahan sebagai penggarap. Sesampainya di rumah mereka harus segera mengerjakan pekerjaan rutin seharihari: memasak, mencuci, mengurus anak, dan tugas domestik lainnya. Kenyataan tersebut sudah menyatu dalam kehidupan buruh tani perempuan di pedesaan dan nyaris menjadi kegiatan yang tak bisa dihindari. Buruh tani perempuan yang merupakan bagian dari wajah kehidupan ini tampil sebagai sosok yang penuh beban dan tanggung jawab.

Buruh tani sebuah profesi di mana seseorang bekerja mengelola lahan milik orang lain karena keterbatasan kepemilikan lahan pertanian, bahkan banyak diantara mereka yang tidak memiliki lahan sama sekali. Sementara itu yang mampu mereka kerjakan hanyalah menggarap lahan pertanian. Buruh tani perempuan diupah sesuai kesepakatan dengan sang pemilik lahan. Profesi buruh tani selalu berkonotasi buruk, identik dengan kenestapaan (kemiskinan).Kehidupan buruh tani perempuan nyaris luput dari perhatian, padahal di dalamnya kerap melahirkan paradoks yang memperihatinkan. Hasil kerja kerasnya, seringkali tidak sepadan dengan perjuangannya dan menjadikan mereka tetap terbelit kemiskinan.

Fenomena ini merupakan salah satu dampak dari masifnya mekanisasi pertanian. Dimana semakin pesatnya alih teknologi pengolahan lahan pertanian dengan menggunakan mesin. Kemunculan tractor, treser (mesin perontok padi), huller (mesin penggiling), transplanter (mesin tanam), dan sebagainya telah menggusur buruh perempuan keluar dari pekerjaan pengolahan lahan pertanian. Teknologi mekanis ini syarat akan maskulinitas dimana laki-laki masih mendominasi dalam penguasaan teknologi. Buruh tani perempuan yang tadinya memiliki peranan dalam penanaman telah tergantikan oleh mesin. Terlebih para petani pemilik lahan lebih memilih efisiensi menggunakan alat-alat tersebut dari pada menggunakan tenaga manual buruh tani perempuan. Efisiensi dan menghemat modal produksi selalu menjadi alasan para petani pemilik lahan.

Ketidaksetaraan atas penguasaan alat ini bukan semata karena adanya lakilaki.Namun justru teknologi yang diciptakan tidaklah ramah gender, sehingga penguasaan atas teknologi tersebut didominasi oleh laki-laki.Stigma yang berkembang di masyarakat pedesaan adalah bahwa laki-laki selalu lebih kuat bekerja dengan alat-alat pertanian dibanding perempuan.Hal ini tentu saja menjadi masalah baru, dimana buruh perempuan semakin muram dan tertindas.

Konsekuensinya, mereka hanya bisa pasrah dengan nasib yang membelenggu. Satu hal yang menjadi perhatian lain adalah keberadaan kaum laki-laki (suami) yang tampaknya belum mampu memenuhi kebutuhan perekonomian keluarga, sehingga masih banyak ditemui pada masyarakat pedesaan dimana para perempuan juga turut serta dalam mencukupi kebutuhan keluarga. Masih banyak dijumpai kaum perempuan menerima beban di luar tanggung jawabnya. Bahkan, ranah pencarian nafkah, perempuan kerap menjadi tulang punggung keluarga, apalagi mereka yang berstatus janda.

Fenomena ini menjadi perhatian kita bersama bahwasannya mekanisasi pertanian yang tujuannya untuk peningkatan produktivitas hasil pertanian hanya terkonsentrasi pada para petani pemilik lahan. Penggunana teknologi pertanian menjadikan modal produksi semakin kecil dan efektif dalam kecepatan menyelesaikan pengolahan lahan yang luas sekalipun. Namun program pemberdayaan petani dan mekanisasi pertanian luput dalam memperhatikan buruh tani perempuan yang notabene mereka tidak memiliki lahan. Jelas di sini, bahwa buruh tani perempuan perlu mendapatkan perhatian yang serius. Permasalahan 
minimnya aset dan kesempatan untuk mengembangkan diri masih menghantui buruh tani perempuan di negara kita.

Pembinaan buruh tani perempuan perlu ditingkatkan dan diberdayakan sebagai receiving system untukmempercepat proses penyerapan teknologi oleh para pekerja perempuan di sektor pertanian. Ditambah lagi dengan strategi perlindungan terhadap tenaga kerja perempuan di pertanian, meningkatkan efektivitas penyuluhan dan pelatihan, perbaikan regulasi, fasilitas, upah, dan kesempatan kerja agar berimbang antar gender. Perlu dikaji lebih lanjut mengenai revitalisasi mekanisme kerja penyuluhan untuk lebih melibatkan buruh tani perempuan dalam mempercepat adopsi teknologi. Hal ini perlu dilakukan sebagai insentif dan keberpihakan terhadap buruh tani perempuan di pedesaan.

\section{Ditulis Oleh Fuat Edi Kurniawan}

Kandidat Peneliti di Pusat Penelitian Kependudukan LIPI

Kontak: edy.fuadegnail.con 